TULIP: Tulisan Ilmiah Pariwisata

E-ISSN: 2720-9873

Available Online at https://journal.umgo.ac.id/index.php/Tulip/index

Vol. 3, No. 1 Juni 2020

DOI: http://dx.doi.org/10.31314/tulip.3.1.1-11.2020

\title{
POTENSI WISATA CURUNG INDAH TEGALREJO GUNUNG KIDUL YOGYAKARTA DENGAN PENDEKATAN ANALISIS SWOT
}

\section{Anggraeni M.S Lagalo}

Program Studi Pariwisata, Universitas Muhammadiyah Gorontalo, Indonesia

Email; anggraenims@umgo.ac.id,

\section{Info Artikel}

Diterima: 20

Mei 2020

Disetujui: 02 Juni 2020

\section{Abstract:}

Some of the trends about increasing human resources are very clearly seen by several well-known tourist attractions in Indonesia, for example, areas that are widely known as tourist attractions in Indonesia are the areas of Bali, Lombok, Yogyakarta, Bandung, Papua, etc. The purpose of this study was to describe the tourism potential of Curung Indah Tegalrejo, Gunung Kidul, Yogyakarta with a SWOT analysis approach with descriptive qualitative research. The results of the study indicate that there is nothing else in advancing a tourist attraction other than the seven charms, in this case: safe, orderly, clean, beautiful, cool, welcoming, and memories are an interrelated unity in the world of tourism. So, for its progress, it takes professionals who are part of the community and government to encourage the continued development of tourist objects in an area in Indonesia.

Keywords: Tourism Potential; Beautiful Curung; SWOT analysis.

\section{Abstrak:}

Beberapa kecenderungan tentang peningkatan SDM ini sangatlah jelas terlihat oleh beberapa tempat wisata yang terkenal di Indonesia, sebut saja wilayah-wilayah yang banyak di kenal sebagai objek wisata di Indonesia adalah wilayah Bali, Lombok, Yogyakarta, Bandung, Papua, dll. Tujuan Penelitian ini adalah mendeskripsikan potensi wisata Curung Indah Tegalrejo Gunung Kidul Yogyakarta dengan Pendekatan Analisis SWOT dengan jenis penelitian kualitatif deskriptif. Hasil penelitian menunjukkan bahwa tidak ada hal lain dalam memajukan suatu objek wisata selain dengan ketujuh sapta pesona tersebut, dalam hal ini: aman, tertib, bersih, indah, sejuk, ramah tamah, dan kenangan merupakan suatu kesatuan yang saling terkait dalam dunia pariwisata. Jadi, untuk kemajuannya dibutuhkan tenaga profesional yang merupakan bagian dari masyarakat dan pemerintah guna mendorong terus berkembangnya objek wisata dalam suatu daerah yang ada di Indonesia ini.

Kata Kunci: Potensi Wisata; Curung Indah; Analisis SWOT

\section{PENDAHULUAN}

$$
\text { Dalam melihat fenomena }
$$

peningkatan pariwisata di Indonesia, perspektif sumber daya manusia menjadi hal yang objektif dan terus menjadi bahan kajian kritis guna menunjang peingkatan dan 
keeksotisan sebuah wilayah objek pariwisata. Objek wisata ini menjadi sangat menarik dikunjungi khsusnya di Indonesia diakibatkan pengelolaannya di tangani oleh sumber daya manusia yang ahli dan terus mengadakan inovasi guna melihat kecenderungan, keunikan objek wisata tersebut.

Pariwisata merupakan industri perdagangan jasa yang dalam kegiatannya semata-mata menjual jasa karena produknya bersifat perishable (hanya dapat dikonsumsi dan dinikmati pada saat berada di suatu tempat) dan sangat berbeda dengan produk perdagangan komesial lainnya yang barangnya bisa dibawa pulang setelah transaksi jual-beli. Pelayanan merupakan hal yang mutlak diperlukan dalam industri pariwisata dan merupakan salah satu tuntutan wisatawan pada saat melakukan kegiatan menghabiskan waktu luang untuk perjalanan wisata. Untuk memberikan jaminan pelayanan yang memuasakan kepada wisatawan diperlukan penyediaan sumber daya manusia (human resources) yang berkompetensi, berkualitas, profesional, dan berstandar internasional. Pada kenyataannya sumber daya manusia pariwisata Bali khususnya, orang-orang Bali belum memiliki kualifikasi yang sesuai dengan permintaan wisatawan. Ini dapat dilihat dengan jelas di kebanyakan industri pariwisata yang mana orang-orang Bali hanya menduduki posisi-posisi sebagai front liner yang memiliki pekerjaan yang cukup berat namun mendapatkan penghasilan yang jauh lebih sedikit daripada posisi-posisi di tingkat manajer (managerial position) yang umumnya dipegang oleh orang-orang dari luar Bali dan bahkan luar negeri .

Sumber daya manusia menjadi kunci utama pengembangan pariwisata. Di tengah tuntutan yang semakin tinggi terhadap perlunya peningkatan kinerja sektor pariwisata agar dapat memenuhi pencapaian target-target ekonometrik, terasa bahwa pembenahan sumber daya manusia dan birokrasi belum kuat disuarakan terdapat kesan yang cukup menonjol bahwa perhatian kita terutama masih bertumpu pada aspek kuantitatif, yakni seberapa besar devisa, kesempatan kerja, kunjungan wisatawan dan sebagainya, sementara aspek kualitatif yang antara lain dilihat dari perubahan positif mutu sumberdaya manusia cenderung diabaikan. Hal ini sebenarnya bertentangan dengan tujuan logika yang mendasari pembangunan pariwisata itu 
sendiri, bahwa target-target ekonomi tersebut hanya dapat dicapai jika persoalan sumberdaya manusia lebih dulu ditangani.

Keikutsertaan sumber daya manusia yang handal memang akan terus membuat objek wisata berkembang dari waktu-kewaktu, walaupun sumber daya manusia dikategorikan sebagai pengelola pasif yang ada dalam struktur pemerintah maupun swasta, bahkan dari insiatif warga sekitar, sumber daya manusia tetaplah menjadi nafas sebuah objek wisata.

Banyak peran yang bisa dimainkan masyarakat dalam pengembangan pariwisata. Masyarakat lokal semestinya dilibatkan dalam proses perencanaan, pembangunan, pengawasan, dan pengevaluasian pariwisata. Namun usaha pelibatan masyarakat dalam pengembangan pariwisata mengalami kendala-kendala dalam penerapannya, karena: (1) sumber daya masyarakat lokal kurang dan bahkan tidak mengetahui visi pembangunan pariwisata secara jelas; (2) rendahnya minat dan kesadaran (awareness) sumber daya masyarakat lokal terhadap pentingnya pariwisata; (3) rendahnya kemampuan sumber daya masyarakat lokal dalam bidang kepariwisataan; (4) kesenjangan budaya (cultural barrier) antara sumber daya masyarakat lokal dan wisatawan; (5) sumber daya masyarakat lokal tidak memiliki kemampuan ekonomi dan investasi .

$$
\text { Faktor-faktor inilah yang }
$$

menjadikan masyarakat lokal hanya menjadi obyek dan penonton saja dan bukan sebagai subyek atau pelaku pariwisata. Masalahmasalah tersebut hanya dapat diatasi dengan pemberian pendidikan dan pelatihan yang cukup atau memadai kepada masyarakat lokal agar memiliki pengetahuan yang lebih luas dan mengglobal. Ini merupakan "PR" dan tantangan yang sangat berat bagi pemerintah dan para pendidik baik itu pendidik di pendidikan dasar, menengah dan perguruan tinggi agar mampu menciptakan sumber daya manusia yang berkompetensi internasional .

Di Kota Yogyakarta sendiri yang terkenal dengan beberapa tempat wisata yang sangat menarik dan banyak dikunjungi oleh wisatawan lokal maupun mancanegara. Curuk Indah sebuah objek wisata yang terletak di Tegal Rejo Yogyakarta adalah salah satu alternative tempat wisata yang banyak dikunjungi, olehnya kemudian pembahasan umum di atas khususnya dalam konteks sumber daya manusia menjadi hal 
yang sangat penting untuk bisa terus diperbaharui guna kemajuan objek wisata dan pengembangan sumber daya manusia itu sendiri.

\section{HASIL DAN PEMBAHASAN}

\section{Pengembangan Sumber Daya Manusia dalam Pariwisata}

Sumber daya manusia pariwisata merupakan orang-orang yang berkecimpung di usaha jasa pariwisata, tidak hanya mengelola dan mengorganisasi tetapi juga memanfaatkannya sebagai mata pencaharian sehari-hari. Secara umum bisa dikatakan kondisi perekonomian Bali pada tahun 2009 lebih baik dibandingkan tahun 2008. Hal ini bisa dilihat dari pertumbuhan ekonomi pada tahun 2009 lebih baik dibandingkan dengan tahun sebelumnya. Pada triwulan III 2009 misalnya, perekonomian Bali tumbuh sebesar 4,17 persen dibandingkan triwulan yang sama tahun sebelumnya. Kondisi ini tentu saja membawa pengaruh positif terhadap kondisi ketenagakerjaan di Bali. Tumbuhnya perekonomian akan meningkatkan kemampuan sektor-sektor ekonomi dalam menyerap tenaga kerja. Tumbuhnya perekonomian Bali mampu menyerap sebanyak 2.057.118 tenaga kerja.
Kondisi ini lebih baik dibandingkan tahun sebelumnya dimana tenaga kerja yang terserap oleh kegiatan ekonomi di Bali hanya sebanyak 2.029.730 orang.

Dampak krisis global mulai mengancam pariwisata Indonesia. Sekitar 20 persen tenaga kerja pariwisata terancam pemutusan hubungan kerja (PHK) pada tahun 2009. Demikian disampaikan Direktur Pusat Data Departemen Kebudayaan dan Pariwisata Harry Waluyo di sela-sela acara UNWTO International Conference on Tourism Statistik di hotel Westin, Nusa Dua, Bali, Senin (30/3/2009). Berdasarkan data, jumlah tenaga kerja pariwisata baik pekerja langsung dan tidak langsung sebanyak 4,41 juta pada tahun 20071.

\section{Analisis SWOT dalam} pengembangan SDM Pariwisata

SWOT adalah singkatan dari Strengths (kekuatan), Weakness (kelemahan), Opportunities (peluang), Threats (tantangan). Analisa SWOT adalah alat yang digunakan untuk mengidentifikasi isu-isu internal dan eksternal yang mempengaruhi kemampuan kita dalam

\footnotetext{
1 Wilfridusa.Djago "Peran Sumberdaya Manusia dalam Pariwisata. 2014 (diakses: http://rinthodjago.blogspot.com/2014/11/makalahmanajemen-transportasi.html)
} 
memasarkan event kita. Analisa SWOT adalah sebuah bentuk analisa situasi dan kondisi yang bersifat deskriptif (memberi gambaran).

Analisa ini terbagi atas empat komponen dasar yaitu :

1. 1. $\mathrm{S}=$ Strength, adalah situasi atau kondisi yang merupakan kekuatan dari organisasi atau program pada saat ini.

2. W = Weakness,.adalah situasi atau kondisi yang merupakan kelemahan dari organisasi atau program pada saat ini.

3. $\mathrm{O}=$ Opportunity, adalah situasi atau kondisi yang merupakan peluang di luar organisasi dan memberikan peluang berkembang bagi organisasi di masa depan.

4. $\mathrm{T}=$ Threat, adalah situasi yang merupakan ancaman bagi organisasi yang datang dari luar organisasi dan dapat mengancam eksistensi organisasi di masa depan.

Dalam dunia pendidikan analisis ini digunakan untuk mengevaluasi fungsi pengembangan kurikulum, fungsi perencanaan dan evaluasi, fungsi ketenagaan, fungsi keuangan, fungsi proses belajar mengajar, fungsi pelayanan kesiswaan, fungsi pengembangan iklim akademik, fungsi hubungan sekolah dengan masyarakat dan sebagainya dilibatkan. Maka untuk mencapai tingkat kesiapan setiap fungsi dan faktor-faktornya dilakukanlah analisis SWOT 2.

Analisis SWOT dilakukan dengan maksud untuk mengenali tingkat kesiapan setiap fungsi dari keseluruhan fungsi sekolah yang diperlukan untuk mencapai sasaran yang telah ditetapkan. Berhubung tingkat kesiapan fungsi ditentukan oleh tingkat kesiapan masing-masing faktor yang terlibat pada setiap fungsi, maka analisis SWOT dilakukan terhadap keseluruhan faktor dalam setiap fungsi, baik faktor

\footnotetext{
2 M. Naufal Akbar, SWOT Sosialisasi Birokrasi, Course Hero. (diakses : https://www.coursehero.com/file/58552137/SWOTSosialisasi-Birokrasi-M-Naufal-Akbar-NIM-120$\operatorname{docx} /$ )
} 
internal maupun eksternal (Depdiknas, 2002).

\section{Objek Wisata Curug Indah Tegalrejo} Ujung Timur Gunung Kidul Yogyakarta.

Curug Indah Tegalrejo ini terletak di Tegalrejo, ujung timur Gunung Kidul, Yogyakarta, masyarakat setempat juga menyebutnya Curug Bayat, karena lokasinya yang berbatasan dengan daerah Bayat, Klaten. Untuk akses menuju ke tempat ini, memang jauh lebih cepat jika kamu melewati Klaten lalu belok ke selatan menuju Bayat. Dari Yogyakarta, anda bisa sampai ke Curug Indah Tegalrejo dalam jangka waktu 1 jam, dengan menggunakan motor atau mobil. Untuk mencapai lokasi Curug pengunjung harus berjalan kaki sekitar 10 menit, dan untuk mencapai curug paling atas harus berjalan kaki lagi sekitar 5 menit melewati jalan setapak, atau juga bisa menyusuri sungai. Mengunjungi curug ini baiknya saat peralihan musim hujan ke kemarau karena menurut warga saat pertengahan musim kemarau airnya kering.

Curug yang masih relatif minim pengunjung ini terdiri dari beberapa curug yang bertingkat dan dinaungi pepohonan hijau di kanan kirinya. Kalau punya nyali bisa mencoba terjun dari atas tebing ke curug di bawahnya. Tapi harus cukup hatihati, karena curugnya cukup dangkal kalau tidak hati-haati malah bisa cidera saat berlibur.

Untuk datang ke Curug ini, anda hanya dipungut biaya parkir yang dikelolah oleh warga sekitar. Di Curug Indah Tegalrejo suasana asri khas pedesaan akan terasa sangat kental. Anda tidak akan sering bertemu sesama turis di sini. Justru warga sekitar dan anak-anak sekolah yang sengaja mampir untuk menyegarkan badan dengan air dari sumber mata air murni lah yang lebih sering kamu jumpai. Damai, tenang, dan tradisional. Begitulah gambaran Curug Indah Tegalrejo.

Melihat perspektif ini kemudian beberapa hal yang dapat dilihat dalam Objek Wisata ini adalah perlunya beberapa pengaturan secara lebih komperhensif agar kemudian dapat lebih memberdayakan masyarakat yang ada di sekitar obyek wisata ini, dalam hal ini objek wisata air terjun ini masih dikelola oleh masyarkat sekitar, itupun untuk bisa merasakan keindahan objek wisata ini hnya dikenakan biaya parkir saja. Oleh sebab itu, pengelolaannya harus lebih professional dengan menggunakan 
beberapa tahapann manajemen yang terstruktur dan di bumbuhi dengan analisis SWOT.

Analisis SWOT adalah identifikasi berbagai faktor - faktor sistematis untuk merumuskan strategi sebuah organisasi baik perusahaan bisnis maupun organisasi sosial. Analisis ini didasarkan pada logika yang dapat memaksimalkan kekuatan (Strength), dan Peluang (opportunities), Namun secara bersamaan dapat meminimalkan kelemahan (weaknessess) dan ancaman (threats). Proses pengambilan keputusan strategis selalu berkaitan dengan pengembangan visi, misi, tujuan, dan kebijakan program-program sebuah organisasi. Dengan demikian perencana strategis (Strategic planner) harus menganalisis faktor-faktor strategis organisasi (kekuatan, kelemahan, peluang, dan ancaman) dalam kondisi yang ada saat ini. Model yang paling populer saat ini adalah analisis SWOT3

\section{Kekuatan (Strength)}

Lokasi Curug Indah Tegalrejo berada di alam terbuka sehingga suasana di tempat ini terasa begitu segar, asri dan

\footnotetext{
${ }^{3}$ Laela Kurniawati, 'Analisis Perencanaan Strategi Teknologi Dan Sistem Informasi Perusahaan', P2M Stimik Bina Insani, 1.2 (2017), 125-38.
}

menyejukkan. Curug Indah Tegalrejo ini terdiri dari beberapa curug yang bertingkattingkat. Masing-masing curug memiliki ketinggian yang bervariasi. Di setiap curug terdapat kolam dibagian bawahnya yang bisa anda gunakan untuk berendam sambil merasakan udara sejuk alam terbuka.

\section{Kelemahan (Weakness)}

Yang menjadi kelemahan dari tempat wisata Curug Indah Tegalrejo ini adalah masih minimnya pengujung yang mungkin dikarenakan jarang tereksplore. Disamping itu juga, karena letaknya yang berada di sudut timur Gunungkidul, terpisah dengan jalur wisata utamanya, sehingga membuat tempat ini masih sepi pengunjung. Curug Indah Tegalrejo ini masih minim fasilitas. Tidak ada toilet, ataupun kamar mandi. Satu-satunya fasilitas yang ada disini adalah tempat parkir yang masih dikelola seadanya oleh masyarakat lokal. Objek wisata Curug Indah ini belum dikelola secara maksimal dan masih dikelolah oleh masyarakat loak. Objek wisata alam di kawasan itu perlu dikembangkan lebih serius. Perlu adanya perpaduan antara pemerintah desa dengan pemilik lahan sekitar Curug Indah apabila ingin mengembangkan objek wisata ini. Kawasan 
ini juga belum dipromosikan secara luas

oleh Pemerintah Kabupaten Gunungkidul.

\section{Peluang (Opportunity)}

Dengan pesona yang ditawarkan oleh obyek wisata Curug Indah Tegalrejo ini dapat memberikan peluang bisnis dalam peningkatan kebutuhan ekonomi masyarakat lokal, serta dapat meningkatkan pendapatan ekonomi daerah tersebut. Tentunya, apabila destinasi wisata ini dikelolah dengan baik dan semaksimal mungkin. Di samping itu, lokasi ini bisa dijadikan peluang pembelajaran tentang ilmu batu-batuan purba (geoheritage), karena sepanjang perjalanan yang menyusuri sungai yang dipenuhi oleh batu-batu.

\section{Ancaman (Threat)}

Ancaman yang mungkin akan dihadapi apabila berkunjung pada obyek wisata Curug Indah Tegalrejo ini adalah dari lokasinya yang merupakan tebing - tebing tinggi, curam dan bertingkat. Apabila kita tidak berhati-hati dalam berjalan kita bisa terpeleset dan jatuh. Karena belum terdapat tanda-tanda peringatan di mana medan yang berbahaya di Curug tersebut.

Dalam membedah Analisis SWOT yang akan di komparasikan dengan objek wisata Curug Indah Tegalrejo, adalah memaksimalkan sebuah perumusan kekuatan dan perencanaan manajemen organisasi, perencanaan ini lebih pada bagaimana mengatur secara dasar tahapantahapan yang bertujuan pada menciptakan peluang yang lebih luas dalam rangka menciptakan penghasilan yang berkesinambungan untuk masyarakat sekitar, olehnya konsep yang terukur dalam sebuah analisis SWOT di akhiri dengan mengurangi bahaya ancaman, ancaman ini dimaksudkan sebagai sebuah kendala yang ditemui oleh pengunjung yang membutuhkan keamanan dari lingkungan sekitar tentunya jaminan oleh masyarakat setempat diperlukan, dari siklus tersebut sebuah tujuan yang dimaksudkan guna untuk menjadikan tempat wisata ini berkembang dalam hal pemanfaatan sumber daya manusia yang ada.

\section{Strategi Pengembangan Obyek Wisata Alam Meliputi \\ Pengembangan}

Dalam melihat beberapa pengembangan Obyek wisata dapat di tarik beberapa hal yang harus menjadi patokan dalam pengembangannya yakni:

Aspek perencanaan pembangunan obyek wisata alam yang antara lain 
mencakup sistem perencanaan kawasan, penataan ruang (tata ruang wilayah), standarisasi, identifikasi potensi, koordinasi lintas sektoral, pendanaan, dan sistem informasi obyek wisata alam. Aspek kelembagaan meliputi pemanfaatan dan peningkatan kapasitas institusi, sebagai mekanisme yang dapat mengatur berbagai kepentingan, secara operasional merupakan organisasi dengan SDM dan peraturan yang sesuai dan memiliki efisiensi tinggi. Aspek sarana dan prasarana yang memiliki dua sisi kepentingan, yaitu (1) alat memenuhi kebutuhan pariwisata alam, (2) sebagai pengendalian dalam rangka memelihara keseimbangan lingkungan, pembangunan sarana dan prasarana dapat meningkatkan daya dukung sehingga upaya pemanfaatan dapat dilakukan secara optimal.

Aspek pengelolaan, yaitu dengan mengembangkan profesionalisme dan pola pengelolaan obyek wisata alam yang siap mendukung kegiatan pariwisata alam dan mampu memanfaatkan potensi obyek wisata alam secara lestari. Aspek pengusahaan yang memberi kesempatan dan mengatur pemanfaatan obyek wisata alam untuk tujuan pariwisata yang bersifat komersial kepada pihak ketiga dan membuka lapangan kerja bagi masyarakat setempat. Aspek pemasaran dengan mempergunakan teknologi tinggi dan bekerja sama dengan berbagai pihak baik dalam negeri maupun luar negeri. Aspek peran serta masyarakat melalui kesempatan-kesempatan usaha sehingga ikut membantu meningkatkan kesejahteraan masyarakat. Aspek penelitian dan pengembangan yang meliputi aspek fisik lingkungan, dan sosial ekonomi dari obyek wisata alam. Diharapkan nantinya mampu menyediakan informasi bagi pengembangan dan pembangunan kawasan, kebijaksanaan dan arahan pemanfaatan obyek wisata alam.

Dalam rangka menemukenali dan mengembangkan obyek wisata alam perlu segera dilaksanakan inventarisasi terhadap potensi nasional obyek wisata alam secara bertahap sesuai prioritas dengan memperhatikan nilai keunggulan saing dan keunggulan banding, kekhasan obyek, kebijaksanaan pengembangan serta ketersediaan dana dan tenaga. Potensi daerah obyek wisata alam yang sudah ditemukenali segera diinformasikan dan dipromosikan kepada calon penanam modal. Dalam rangka optimalisasi fungsi obyek wisata alam perlu diupayakan 
pengembangan pendidikan konservasi melalui pengembangan sistem interprestasi obyek wisata alam dan kerjasama dengan instansi terkait termasuk lembaga-lembaga pendidikan, penelitian, penerangan masyarakat, dan lain-lain.

Perlu dikembangkan sistem kemitraan dengan pihak swasta, lembaga swadaya masyarakat yang ada, dalam rangka mendukung optimalisasi pengembangan obyek wisata alam. Pengembangan obyek wisata alam merupakan sub-sistem dari pengembangan pariwisata daerah dan pengembangan wilayah pada umumnya yang secara langsung maupun tidak langsung memberi manfaat lebih bagi masyarakat setempat. Peranan pemerintah daerah dalam pengembangan obyek wisata ini melaksanakan koordinasi, perencanaan, pelaksanaan serta monitoring pengembangan obyek wisata alam.

\section{KESIMPULAN}

Tujuh sapta pesona dalam bidang pariwisata merupakan hal yang sangat penting, yang pertama yakni, keamanan. Keamanan seseorang dalam perjalanannya untuk bersenang-senang sangat penting, jangan sampai ada yang melakukan aksi pencurian apa lagi sampai membahayakan nyawa para wisatawan. Kedua, ketertiban. ketertiban dalam daerah tujuan wisata tersebut juga sangat diperlukan dimana dengan adanya kebiasaan-kebiasaan yang terampil dan tertib, tidak ada pemberontak atau pengacau maka dapat menimbulkan nuansa hidup baru pengunjung dalam beradaptasi. Ketiga, kebersihan adalah satu cara untuk membuat hati damai, tidak berantakan, tidak merasa sedih dalam melihat pemandangan yang kurang memuaskan, contohnya suatu daerah pantai tidak bersih sehingga membuat para wisatawan yang sebenarnya ingin menikmati keindahan alam malah melihat pemandangan yang jelek. Empat, kekayaan keindahan alam yang dimiliki oleh negara Indonesia dengan posisi yang sangat strategis, sebenarnya sudah sangat mendukung kemajuan suatu objek wisata, akan tetapi dalam pengelolaannya masih sangat kurang sehingga panorama keindahan alamnyapun semakin menurun. Lima, kesejukan suatu daerah harus mendukung dalam hal lingkungan yang tertata dengan rapi, banyak pohon-pohon yang menghijau sehingga ketika ada tiupan angin nafas terasa segar. Enam, keramahtamahan suatu 
lingkungan adalah halyang sangat utama dalam memajukan kepariwisataan, disebabkan terlihatnya menarik suatu daerah atau betahnya para wisatawan ditentukan oleh keramahan daerah tersebut dan bagaimana tata cara menerima orang lain yang masuk dalam daerahnya. Ketujuh adalah kenangan yang tidak lain adalah kekeluargaan yang sifatnya saling mengingat akan segala sesuatu apa yang telah dilakukan baik seorang pengunjung (wisatawan) maupun seorang yang memberi pelayanan.

\section{REFERENSI}

Kurniawati, Laela, 'Analisis Perencanaan Strategi Teknologi Dan Sistem Informasi Perusahaan', P2M Stimik Bina Insani, 1.2 (2017), 125-38

Damanik, Janianton dan Frans Teguh, 2012, Manajemen Destinasi Pariwisata,
Sebuah Pengantar Ringkas, Yogyakarta: Kepel Press.

Prof. Dr. I Gusti Bagus Arjana,M.S., 2015, Geografi Pariwisata dan Ekonomi Kreatif, Jakarta: PT RajaGrafindo Persada.

M. Naufal Akbar, SWOT Sosialisasi Birokrasi, Course Hero. (diakses https://www.coursehero.com/file/5855213 7/SWOT-Sosialisasi-Birokrasi-M-NaufalAkbar-NIM-120-docx/)

Wilfridusa.Djago "Peran Sumberdaya Manusia dalam Pariwisata. 2014 (diakses: http://rinthodjago.blogspot.com/2014/11/ makalah-manajemen-transportasi.html) 